\title{
DNA binding, topoisomerase inhibition and cytotoxicity of palladium(II) complexes with 1,10-phenanthroline and thioureas
}

\author{
Carolina V. Barra ${ }^{\mathrm{a}, \mathrm{b}, *}$, Fillipe V. Rocha ${ }^{\mathrm{c}}$, Laurent Morel ${ }^{\mathrm{d}}$, Arnaud Gautier ${ }^{\mathrm{e}}$, Saulo S. Garrido ${ }^{\mathrm{f}}$, \\ Antonio E. Mauro ${ }^{a}$, Regina C.G. Frem ${ }^{a}$, Adelino V.G. Netto ${ }^{\mathrm{a}, *}$ \\ a Departamento de Química Geral e Inorgânica, Instituto de Química, UNESP, CEP 14801-970 Araraquara, SP, Brazil \\ ${ }^{\mathrm{b}}$ Instituto Federal de Educação, Ciência e Tecnologia, CEP 14801-600 Araraquara, SP, Brazil \\ ${ }^{\mathrm{c}}$ Departamento de Química, Universidade Federal de São Carlos, CEP 13565-905 São Carlos, SP, Brazil \\ ${ }^{\mathrm{d}}$ Clermont-Université, Université Blaise Pascal, GreD UMR 6247 CNRS, INSERM U931, 24 Avenue des Landais, 63177 Aubière Cedex, France \\ e Clermont-Université, ICCF, Université Blaise Pascal, CNRS, UMR 6296, 63177 Aubière Cedex, France \\ ${ }^{\mathrm{f}}$ Departamento de Bioquímica e Tecnologia Química, Instituto de Química, UNESP, CEP 14801-970 Araraquara, SP, Brazil
}

\section{A R T I C L E I N F O}

\section{Article history:}

Received 10 September 2015

Received in revised form 20 January 2016

Accepted 24 February 2016

Available online 3 March 2016

\section{Keywords:}

Palladium(II)

Thioureas

Metallointercalator

Cytotoxicity

DNA binding

Topoisomerase inhibitors

\begin{abstract}
A B S T R A C T
Metallointercalators represent a promising alternative in cancer chemotherapy. We present herein DNA binding, topoisomerase inhibition and cytotoxic studies on a series of complexes of general formulae [Pd (phen) $\left.\left(\mathrm{tu}^{*}\right)_{2}\right]^{2+}$ incorporating the intercalator 1,10-phenanthroline and thiourea ligands $(\mathrm{L}=$ thiourea $\mathbf{1}$, $\mathrm{N}$-methylthiourea 2, N,N'-dimethylthiourea 3). DNA-unwinding results showed that the complexes can induce the unwinding of the plasmid DNA. The binding constants $\left(K_{\mathrm{b}}\right)$ for the interaction of the complexes with SS-DNA were determined by UV spectroscopy. Competitive experiments with ethidium bromide (EB) were investigated by fluorescence spectroscopy and show that all the complexes were able to displace EB from the DNA-EB complex. The results suggest that they may interact with DNA by intercalation. Compounds were tested against human oral carcinoma cell line (KB), human breast cancer cell line (MCF7) and cisplatin-resistant human breast cancer cell line (MCF7-R) and showed good cytotoxic activity towards MCF7-R. Compounds 2 and $\mathbf{3}$ were also able to cause topo II inhibition.
\end{abstract}

(c) 2016 Elsevier B.V. All rights reserved.

\section{Introduction}

Metal complexes have been used as antitumor agents since the discovery of the biological activity of cisplatin in the late-1960 s [1]. Despite the efforts to develop new metal-based anticancer agents, with the aim to overcome cisplatin resistance and side effects, only carboplatin and oxaliplatin have also received worldwide approval for clinical practice [2]. Since cisplatin and its analogous exhibit similar spectrum of activity, it is generally accepted that these drugs share the same mechanism of action. Their antitumor effect is the result of covalent adducts with DNA that induce cell apoptosis. Thus in order to develop more effective drugs it is necessary to design agents capable to produce damages in DNA by different binding strategies such as electrostatic binding, hydrophobic binding to the minor groove and intercalation [3].

* Corresponding authors at: Departamento de Química Geral e Inorgânica, Instituto de Química, UNESP, CEP 14801-970 Araraquara, SP, Brazil (C.V. Barra).

E-mail addresses: carolvbr@gmail.com (C.V. Barra), adelino@iq.unesp.br (A.V.G. Netto)
The process by which a molecule interacts with DNA by insertion of its planar moiety between adjacent base pairs of the double helix is denoted intercalation [4], which was first demonstrated by Lerman through his studies into the binding of acridines to DNA [5]. Classical intercalators are organic compounds whose structures are characterized by the presence of a planar aromatic moiety, commonly comprised of fused rings, such as acridines, anthracyclines and phenanthridines [6]. Intercalation can produce deep alterations in the nucleotide secondary structure, such as lengthening, stiffening and unwinding of the DNA helix, with major consequences for DNA replication and transcription [7]. DNA intercalating molecules (e.g. doxorubicin and mitoxantrone) comprise a significant proportion of some of the most potent drugs currently available for the cancer chemotherapy [6]. Besides their ability to intercalate to DNA, these antineoplastic agents also target topoisomerase II and their cytotoxic activity may be mediated by the formation of an intermediate covalent DNA-topoisomerase II complex (termed cleavable complex), resulting in cell death via apoptosis [8].

Although first observed for organic molecules, DNA intercalation is also possible with metal complexes if they possess at least 
one planar aromatic ligand, such as 1,10-phenanthroline (phen), dipyrido[3,2-a:2', 3'-c]phenazine (dppz) or 2,2',2"-terpyridine (terpy) [7,9-12]. The incorporation of transition metal centres into such structures can not only be used to impart cationic charge, but also to confer new properties on these molecules, such as magnetism, redox activity, luminescence properties [7,9-12]. Over the last few years, there has been a rapid expansion in the research area of square-planar $d^{8}$ metal complexes incorporating the flat " $\mathrm{M}$ $(\mathrm{N}, \mathrm{N})$ " moiety ( $\mathrm{N}, \mathrm{N}=2,2^{\prime}$-bipyridine, 1,10-phenanthroline; $\mathrm{M}=\mathrm{Pd}$, $\mathrm{Pt})$ due to its ability to intercalate DNA [13-15]. According to literature, not only modifications in the intercalator ligand, but also in the ancillary ligand, lead to changes in the binding modes, drug DNA association constants and cytotoxicity [16,17]. Recently, a study on complexes of the type $[\mathrm{Pt}(\mathrm{N}-\mathrm{N})(\mathrm{L}-\mathrm{L})]^{2+}(\mathrm{N}-\mathrm{N}=$ phenanthroline derivatives, $\mathrm{L}-\mathrm{L}=$ bidentate ancillary ligand) highlighted the influence of the ancillary ligand, particularly in terms of interactions with non-DNA receptors [18].

In this sense, the incorporation of thioureas as ancillary ligands in mixed compounds of the type $\left[\mathrm{M}(\text { phen })\left(\mathrm{tu}^{*}\right)_{2}\right]^{+2}(\mathrm{M}=\mathrm{Pd}(\mathrm{II}), \mathrm{Pt}$ (II); tu = thioureas) has emerged as a promising strategy to design new anticancer metal compounds with intercalating properties. Thiourea type-ligands exchange more slowly and have been employed in order to avoid competitive covalent interactions towards biomolecules [19]. The efforts by Cusumano's group [20-22] on these compounds have provided important information about their solution behavior and non-covalent DNA interactions. In addition, Marverti et al. have also proposed a structure-activity relationship studies with platinum-intercalators of general formulae $\left[\mathrm{Pt}(\mathrm{N}-\mathrm{N})\left(\mathrm{tu}^{*}\right)_{2}\right]^{2+} \quad(\mathrm{N}-\mathrm{N}=$ phenanthroline derivatives, $\mathrm{tu}^{*}=$ thioureas) and observed that changing the ligand environment can tune the cytotoxicity [23].

Despite the extensive work devoted to this class of compounds, studies on the profiles of DNA binding and cytotoxic properties of complexes of general formulae $\left[\mathrm{Pd}(\text { phen })\left(\mathrm{tu}^{*}\right)_{2}\right]^{2+}($ Fig. 1) are scarce in the literature. Inspired by the promising anticancer activity of metallointercalators and giving continuity to our research in coordination and biological chemistry of $\mathrm{Pd}(\mathrm{II})$ complexes [24-27], we present herein the biological studies on the compounds $[\mathrm{Pd}(\mathrm{phen})$ $\left.(\mathrm{tu})_{2}\right] \mathrm{Cl}_{2} \cdot 2 \mathrm{H}_{2} \mathrm{O}(\mathbf{1}),\left[\mathrm{Pd}(\mathrm{phen})(\mathrm{mtu})_{2}\right] \mathrm{Cl}_{2} \cdot 3 \mathrm{H}_{2} \mathrm{O}(\mathbf{2})$, and $[\mathrm{Pd}($ phen $)$

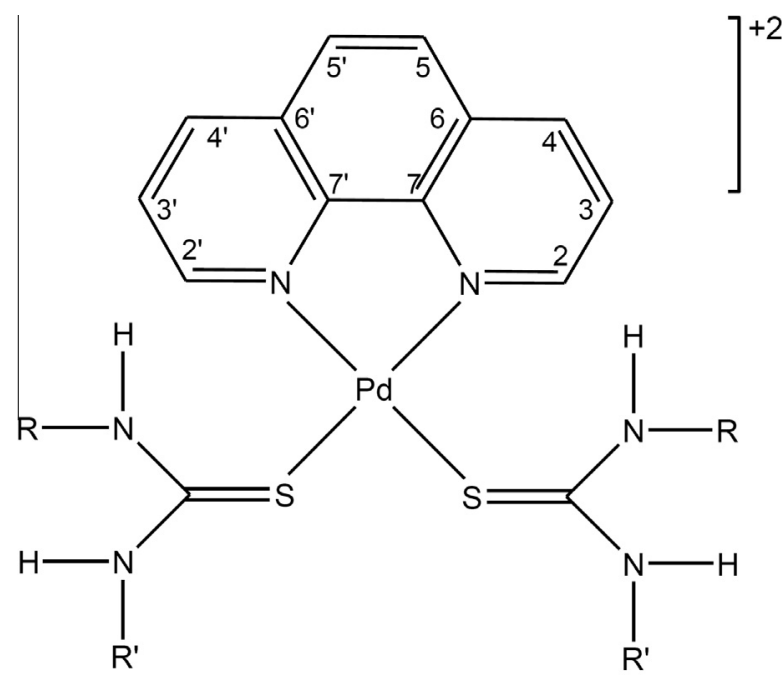

1; $\mathrm{R}=\mathrm{R}^{\prime}=\mathrm{H}$

2; $\mathrm{R}=\mathrm{H} ; \mathrm{R}^{\prime}=\mathrm{CH}_{3}$

3; $\mathrm{R}=\mathrm{R}^{\prime}=\mathrm{CH}_{3}$

Fig. 1. General structure of the palladium complexes $\left[\mathrm{Pd}(\mathrm{phen})(\mathrm{tu})_{2}\right] \mathrm{Cl}_{2} \cdot 2 \mathrm{H}_{2} \mathrm{O}$ (1), $\left[\mathrm{Pd}(\right.$ phen $\left.)(\mathrm{mtu})_{2}\right] \mathrm{Cl}_{2} \cdot 3 \mathrm{H}_{2} \mathrm{O}(\mathbf{2})$, and $\left[\mathrm{Pd}(\right.$ phen $\left.)(\mathrm{dmtu})_{2}\right] \mathrm{Cl}_{2} \cdot 3 \mathrm{H}_{2} \mathrm{O}(\mathbf{3})$. $\left.(\mathrm{dmtu})_{2}\right] \mathrm{Cl}_{2} \cdot 3 \mathrm{H}_{2} \mathrm{O} \quad$ (3), tu = thiourea; $\mathrm{mtu}=\mathrm{N}$-methylthiourea; $\mathrm{dmtu}=\mathrm{N}, \mathrm{N}^{\prime}$-dimethylthiourea. Here, the profiles of DNA binding, topoisomerase inhibition and cytotoxic properties of 1-3 have been presented.

\section{Materials and methods}

\subsection{Materials and instrumentation}

${ }^{1} \mathrm{H}$ and ${ }^{13} \mathrm{C}\left\{{ }^{1} \mathrm{H}\right\}$ NMR spectra were registered at $298 \mathrm{~K}$, in $\mathrm{CD}_{3} \mathrm{OD}$ solution, on a Varian model Inova 500 spectrometer operating at 500 and $126 \mathrm{MHz}$, respectively. Data are reported as chemical shifts $(\delta)$ in ppm. Residual solvent signals were used as internal references $\left({ }^{1} \mathrm{H},{ }^{13} \mathrm{C}\right)$. IR spectra were recorded on a Spectrum 200 from Perkin Elmer, in a range between 4000 and $400 \mathrm{~cm}^{-1}$ using $\mathrm{KBr}$ pellets. Elemental analyses were performed by the Central Analítica at IQ-University of São Paulo, Brazil. Conductivities were measured with a Digimed-DM-31 conductometer using $1 \times 10^{-3} \mathrm{~mol} \mathrm{~L}^{-1}$ solutions in methanol. Electronic absorption spectra were recorded on a Perkin-Elmer LAMBDA 25 spectrophotometer in a $10 \mathrm{~mm}$ quartz cell. Fluorescence spectra were registered on a Varian Cary Eclipse fluorescence spectrophotometer. The sample was excited at $526 \mathrm{~nm}$ and its emission spectra were scanned in the range $550-700 \mathrm{~nm}$.

\subsection{Synthesis of the complexes}

The starting complexes $\left[\mathrm{PdCl}_{2}\left(\mathrm{CH}_{3} \mathrm{CN}\right)_{2}\right]$ and $\left[\mathrm{Pd}(\mathrm{phen}) \mathrm{Cl}_{2}\right]$ were prepared according to literature procedures $[28,29]$. The complexes $\left[\mathrm{Pd}(\right.$ phen $\left.)(\mathrm{tu})_{2}\right] \mathrm{Cl}_{2}(\mathbf{1})$ and $\left[\mathrm{Pd}(\right.$ phen $\left.)(\mathrm{mtu})_{2}\right] \mathrm{Cl}_{2}(\mathbf{2})$ were prepared as previously described by Rotondo et al. [21].

\subsection{1. $\left[\mathrm{Pd}(\right.$ phen $\left.)(\mathrm{tu})_{2}\right] \mathrm{Cl}_{2} \cdot 2 \mathrm{H}_{2} \mathrm{O}(\mathbf{1})$}

Dark orange solid. Elemental Anal. Calc. for $\mathrm{C}_{14} \mathrm{H}_{16} \mathrm{Cl}_{2} \mathrm{~N}_{6} \mathrm{PdS}_{2}$. $2 \mathrm{H}_{2} \mathrm{O}: \mathrm{C}, 30.81 ; \mathrm{H}, 3.69 ; \mathrm{N}, 15.40$. Found: C, 30.21; H, 3.73; N, 15.37\%. ${ }^{1} \mathrm{H}$ NMR (500 MHz, $\left.\mathrm{CD}_{3} \mathrm{OD}\right): \delta$ (ppm) 9.46 [dd, J(3, 9), $2 \mathrm{H}$, $\mathrm{H}-2$ ]; 8.96 [dd, $J(3,14), 2 \mathrm{H}, \mathrm{H}-4$ ] ; 8.29 [s, 2H, H-5]; 8.16 [dd, $J(9$, 14), $2 \mathrm{H}, \mathrm{H}-3$ ]. ${ }^{13} \mathrm{C}$ NMR (125 MHz, CD $\left.{ }_{3} \mathrm{OD}\right): \delta$ (ppm) 125.9 [C-3]; 127.8 [C-5]; 131.3 [C-6]; 140.6 [C-4]; 147.2 [C-7]; 150.0 [C-2]; $177.4[\mathrm{C}=\mathrm{S}]$. IR $\left(\mathrm{KBr}, \mathrm{cm}^{-1}\right)$ : 3269, $3102(\mathrm{vNH}) ; 1617(\delta \mathrm{NH})$; 1514, 1424 ( $\left.\mathrm{VCC}_{\text {ring }}\right) ; 854,784,716\left(\gamma \mathrm{CH}_{\text {ring }}\right) ; 671$ ( $\left.\mathrm{vCS}\right)$. UV-Vis (in buffer $10 \mathrm{mM}$ tris- $\mathrm{HCl}, 10 \mathrm{mM} \mathrm{NaCl}, \mathrm{pH} \mathrm{7.2):} \varepsilon_{268 \mathrm{~nm}}=22278$ $\mathrm{M}^{-1} \mathrm{~cm}^{-1}$. $\Lambda_{\mathrm{M}}=213 \Omega^{-1} \mathrm{~cm}^{2} \mathrm{~mol}^{-1}$ in methanol. Yield: $96 \%$.

\subsection{2. $\left[\mathrm{Pd}(\right.$ phen $\left.)(\mathrm{mtu})_{2}\right] \mathrm{Cl}_{2} \cdot 3 \mathrm{H}_{2} \mathrm{O}(\mathbf{2})$}

Red brown solid. Elemental Anal. Calc. for $\mathrm{C}_{16} \mathrm{H}_{20} \mathrm{Cl}_{2} \mathrm{~N}_{6} \mathrm{PdS}_{2}$. $3 \mathrm{H}_{2} \mathrm{O}$ : C, 32.47; H, 4.43; N, 14.20. Found: C, 32.47; H, 4.19; N, 14.48\%. ${ }^{1} \mathrm{H}$ NMR (500 MHz, $\left.\mathrm{CD}_{3} \mathrm{OD}\right): \delta$ (ppm) 9.45 [dd, $J(2,9), 2 \mathrm{H}$, $\mathrm{H}-2$ ]; 8.96 [dd, $J(2,14), 2 \mathrm{H}, \mathrm{H}-4$ ]; 8.29 [s, 2H, H-5]; 8.15 [dd, $J(9$, 14), $2 \mathrm{H}, \mathrm{H}-2$ ]; $2.92\left[\mathrm{~s}, 6 \mathrm{H}, \mathrm{CH}_{3}\right] .{ }^{13} \mathrm{C}$ NMR $\left(125 \mathrm{MHz}, \mathrm{CD}_{3} \mathrm{OD}\right): \delta$ (ppm) $29.6\left[\mathrm{CH}_{3}\right] ; 125.9$ [C-3]; 127.8 [C-5]; 131.3 [C-6]; 140.6 [C-4]; 147.2 [C-7]; 149.9 [C-2]. IR $\left(\mathrm{KBr}, \mathrm{cm}^{-1}\right): 3280,3144,3071$ $(\mathrm{vNH}) ; 1638(\delta \mathrm{NH}) ; 1577(\mathrm{VCN}) ; 1515,1424$ ( $\left.\mathrm{VCC}_{\text {ring }}\right) ; 850,770$, $716\left(\gamma \mathrm{CH}_{\text {ring }}\right)$; 633 ( $\left.\mathrm{vCS}\right)$. UV-Vis (in buffer $10 \mathrm{mM}$ tris- $\mathrm{HCl}$, $10 \mathrm{mM} \mathrm{NaCl}, \mathrm{pH} 7.2): \varepsilon_{271 \mathrm{~nm}}=23820 \mathrm{M}^{-1} \mathrm{~cm}^{-1} \cdot \Lambda_{\mathrm{M}}=197 \Omega^{-1}$ $\mathrm{cm}^{2} \mathrm{~mol}^{-1}$ in methanol. Yield: $85 \%$.

\subsection{3. $\left[\mathrm{Pd}(\right.$ phen $\left.)(\mathrm{dmtu})_{2}\right] \mathrm{Cl}_{2} \cdot 3 \mathrm{H}_{2} \mathrm{O}$ (3)}

An aqueous suspension of $\left[\mathrm{Pd}(\right.$ phen $\left.) \mathrm{Cl}_{2}\right](0.2 \mathrm{mmol})$ in $40 \mathrm{~mL}$ of water ( $\mathrm{pH}$ 6.5) was heated under reflux and then a solution containing $\mathrm{N}, \mathrm{N}^{\prime}$-dimethylthiourea $(0.4 \mathrm{mmol})$ in $5.0 \mathrm{~mL}$ of water was added, affording a red-brownish solution. The reaction mixture was stirred for $1 \mathrm{~h}$ under reflux. The obtained solution was filtered to eliminate any excess of $\left[\mathrm{Pd}(\mathrm{phen}) \mathrm{Cl}_{2}\right]$. After solvent evaporation, at room temperature, a crystalline solid was obtained. 
Dark yellow solid. Elemental Anal. Calc. for $\mathrm{C}_{18} \mathrm{H}_{24} \mathrm{Cl}_{2} \mathrm{~N}_{6} \mathrm{PdS}_{2}$. $3 \mathrm{H}_{2} \mathrm{O}: \mathrm{C}, 34.87 ; \mathrm{H}, 4.88 ; \mathrm{N}, 13.56$. Found: $\mathrm{C}, 34.26 \mathrm{H}, 4.51 ; \mathrm{N}$, 13.02\%. ${ }^{1} \mathrm{H}$ NMR (500 MHz, $\left.\mathrm{CD}_{3} \mathrm{OD}\right): \delta$ (ppm) 9.31 [dd, $J($ n.d., 9 ), $2 \mathrm{H}, \mathrm{H}-2$ ]; 8.93 [dd, J(n.d., 14), 2H, H-4]; 8.26 [s, 2H, H-5]; 8.11 [dd, $J(9,14), 2 \mathrm{H}, \mathrm{H}-3]$; $3.27\left[\mathrm{~s}, 6 \mathrm{H}, \mathrm{CH}_{3}\right] ; 2.88\left[\mathrm{~s}, 6 \mathrm{H}, \mathrm{CH}_{3}\right] .{ }^{13} \mathrm{C}$ NMR (125 MHz, CD $3 \mathrm{OD}): \delta(\mathrm{ppm}) 30.4\left[\mathrm{CH}_{3}\right] ; 32.6\left[\mathrm{CH}_{3}\right] ; 127.1$ [C-3]; 129.0 [C-5]; 132.6 [C-6]; 141.8 [C-4]; 148.4 [C-7]; 151.1 [C-2]; $174.9[\mathrm{C}=\mathrm{S}]$. IR $\left(\mathrm{KBr}, \mathrm{cm}^{-1}\right): 3206(\mathrm{VNH}) ; 1592(\mathrm{VCN})$; 1515,1426 ( $\left.\mathrm{VCC}_{\text {ring }}\right) ; 850,778,718\left(\gamma \mathrm{CH}_{\text {ring }}\right) ; 650$ ( $\left.\mathrm{vCS}\right)$. UV-Vis (in buffer $10 \mathrm{mM}$ tris- $\mathrm{HCl}, 10 \mathrm{mM} \mathrm{NaCl}, \mathrm{pH} \mathrm{7.2):} \varepsilon_{275} \mathrm{~nm}=19400$ $\mathrm{M}^{-1} \mathrm{~cm}^{-1} . \Lambda_{\mathrm{M}}=161 \Omega^{-1} \mathrm{~cm}^{2} \mathrm{~mol}^{-1}$ in methanol. Yield: $92 \%$.

\subsection{Stability studies}

The stabilities of complexes 1-3 were studied by monitoring their ${ }^{1} \mathrm{H}$ NMR spectra in a mixture tris- $\mathrm{HCl}$ buffer $/ \mathrm{D}_{2} \mathrm{O}$ over $48 \mathrm{~h}$.

\subsection{Interaction with guanosine}

Guanosine ( $0.022 \mathrm{mmol}, 2.0$ equiv) dissolved in $0.5 \mathrm{~mL}$ of $\mathrm{D}_{2} \mathrm{O}$ (pD 7.9) was added to a solution of the complex $(0.011 \mathrm{mmol}$, 1.0 equiv) in $0.5 \mathrm{~mL}$ of $\mathrm{D}_{2} \mathrm{O}$. The reaction was kept under agitation for $48 \mathrm{~h} .{ }^{1} \mathrm{H}$ NMR spectra were recorded after $1,2,24$ and $48 \mathrm{~h}$ of reaction.

\subsection{Interaction with supercoiled plasmid}

Solutions $(1 \mu \mathrm{M}, 10 \mu \mathrm{M}$ and $100 \mu \mathrm{M})$ of the complexes were prepared in water ( $\mathrm{pH}$ 6.9). $19.0 \mu \mathrm{L}$ of each solution was added to $1.0 \mu \mathrm{L}$ of pNFkB-luc plasmid, then incubated for $24 \mathrm{~h}$. Samples were analyzed by agarose gel electrophoresis (1\% agarose gel in $0.5 \times$ tris-acetic acid EDTA buffer, pH 7.9, $100 \mathrm{~V}$ ). The gel was revealed with EB under UV-light.

\subsection{DNA binding studies}

Salmon sperm DNA (SS-DNA) has been purchased from Sigma Aldrich and used as received. All the experiments involving SSDNA were carried out in the buffer $10 \mathrm{mM}$ tris- $\mathrm{HCl}, 10 \mathrm{mM} \mathrm{NaCl}$, $\mathrm{pH} 7.2$ at room temperature. A stock solution $\left(1 \mathrm{mg} \mathrm{mL}^{-1}\right)$ was prepared by dissolving the SS-DNA in the buffer and it gave a ratio of UV absorbance at 260 and $280 \mathrm{~nm}\left(\mathrm{~A}_{260} / \mathrm{A}_{280}\right)$ of 1.80 , indicating that the DNA was sufficiently free of protein contamination [30]. The reported molar extinction coefficient of $6600 \mathrm{M}^{-1} \mathrm{~cm}^{-1}$ at $260 \mathrm{~nm}$ was used to determine the DNA concentration [31].

\subsubsection{Spectroscopic titration}

UV spectroscopy has been used to determine the binding constants $\left(K_{\mathrm{b}}\right)$ for the interaction of the complexes with DNA. The titrations were performed by adding increasing amounts of DNA to a fixed amount of the complex $(40 \mu \mathrm{M})$ over a range of ratio $0.2-2$ ([DNA]/[complex]). The electronic absorption spectra have been recorded after each addition of DNA and equilibration (ca. $5 \mathrm{~min}$ ). While measuring the absorption spectra, an equal amount of DNA was added to both complex solution and reference solution to eliminate the absorbance of DNA itself. Changes in absorbance were monitored at the maximum wavelengths of 268, 271 and $275 \mathrm{~nm}$ for 1, 2 and 3, respectively. The intrinsic binding constants, $K_{\mathrm{b}}$, for the binding of the complexes to DNA have been calculated by the following equation:

$[\mathrm{DNA}] /\left(\varepsilon_{\mathrm{A}}-\varepsilon_{\mathrm{F}}\right)=[\mathrm{DNA}] /\left(\varepsilon_{\mathrm{B}}-\varepsilon_{\mathrm{F}}\right)+1 / K_{\mathrm{b}}\left(\varepsilon_{\mathrm{B}}-\varepsilon_{\mathrm{F}}\right)$

where $\varepsilon_{\mathrm{A}}, \varepsilon_{\mathrm{F}}, \varepsilon_{\mathrm{B}}$ correspond to $A_{\mathrm{obsd}} /[$ complex], the extinction coefficient for the free complex, and the extinction coefficient for the complex in the fully bound form, respectively. In plots of [DNA]/
$\left(\varepsilon_{\mathrm{A}}-\varepsilon_{\mathrm{F}}\right)$ versus [DNA], $K_{\mathrm{b}}$ is given by the ratio of the slope to the intercept [32].

\subsubsection{Competitive studies with ethidium bromide}

In order to check the ability of the complexes to displace ethidium bromide (EB) from a DNA-EB complex, fluorescence quenching experiments have been performed. Small amounts of the complexes solution $(4 \mathrm{mM})$ were added to a solution of DNA $(25 \mu \mathrm{M})$ pretreated with EB $(5 \mu \mathrm{M})$ in buffer ([complex]/[DNA] $=0-2.255$ ). Changes in the fluorescence intensity have been verified exciting the samples at $526 \mathrm{~nm}$. The emission spectra have been recorded in the range from 550 to $700 \mathrm{~nm}$.

\subsection{Topoisomerase inhibition}

Human topoisomerase II was supplied as reaction kit by Inspiralis Limited (Norwich, UK). The inhibition assay was conducted from the reaction mixture $(30 \mathrm{~mL})$ containing $10 \mathrm{mM}$ Tris- $\mathrm{HCl}$ (pH 7.9), $50 \mathrm{mM} \mathrm{NaCl}, 50 \mathrm{mM} \mathrm{KCl}, 5.0 \mathrm{mM} \mathrm{MgCl} 2,0.1 \mathrm{mM} \mathrm{Na}_{2} \mathrm{H}_{2}$ EDTA, $15 \mathrm{mg} \mathrm{mL}^{-1}$ BSA (bovine serum albumin), $1.0 \mathrm{mM}$ ATP (adenosine triphosphate), $500 \mathrm{ng}$ pBR322 plasmid DNA, $4.0 \mathrm{nmol}^{-1}$ Topo II and complexes. The reaction mixtures were incubated at $37{ }^{\circ} \mathrm{C}$ for $1 \mathrm{~h}$. The reaction was stopped by the addition of $3 \mathrm{~mL}$ SDS (sodium dodecyl sulfate), $15 \mathrm{~mL}$ STEB (reaction stop buffer) and $60 \mathrm{~mL}$ chloroform: isoamyl alcohol $(24: 1 \mathrm{v} / \mathrm{v})$ mixture, then centrifuged and analyzed. The samples were electrophoresed at $60 \mathrm{~V}$ for $2 \mathrm{~h}$, the gel was stained with ethidium bromide solution $\left(1 \mathrm{mg} \mathrm{mL}^{-1}\right)$ and analyzed by an Alpha Imager EP System of Alpha Innotech.

\subsection{Cytotoxicity assays}

Compounds were tested against KB, MCF7 and MCF7-R cell lines. Cells were maintained as monolayers in Dulbecco's Modified Eagle's Medium (DMEM) or RPMI (cell culture medium) supplemented with $10 \%$ fetal calf serum, $2 \mathrm{mM}$ glutamin and $1 \mathrm{X}$ gentamicin at $37{ }^{\circ} \mathrm{C}$ in a humidified atmosphere under $5 \% \mathrm{CO}_{2}$. For cytotoxic assay, $5 \times 10^{3}$ cells were seeded in 96-well plates and incubated $24 \mathrm{~h}$ at $37^{\circ} \mathrm{C}$. The cells were then exposed for $48 \mathrm{~h}$ to $1 \mu \mathrm{M}$ and $10 \mu \mathrm{M}$ of the complexes. The effect of each compound on cell outgrowth was determined by the MTT assay in triplicate [33].

\section{Results and discussion}

Compounds $\left[\mathrm{Pd}(\right.$ phen $\left.)(\mathrm{tu})_{2}\right] \mathrm{Cl}_{2} \cdot 2 \mathrm{H}_{2} \mathrm{O}(\mathbf{1})$ and $\left[\mathrm{Pd}(\right.$ phen $\left.)(\mathrm{mtu})_{2}\right]$ $\mathrm{Cl}_{2} \cdot 3 \mathrm{H}_{2} \mathrm{O}$ (2) have been synthesized as described by Rotondo et al. [21]. Complex $\left[\mathrm{Pd}(\right.$ phen $\left.)(\mathrm{dmtu})_{2}\right] \mathrm{Cl}_{2} \cdot 3 \mathrm{H}_{2} \mathrm{O}$ (3) was obtained similarly as $\mathbf{1}$ and $\mathbf{2}$ by reacting $\left[\mathrm{PdCl}_{2}\right.$ (phen)] with $\mathrm{N}, \mathrm{N}^{\prime}-$ dimethylthiourea (dmtu). The syntheses were carried out under reflux and constant magnetic stirring. Complexes are air stable solids and exhibit colors that vary from dark yellow to red. The molar conductivities of complexes 1-3 in methanol are between 161 and $213 \mathrm{ohm}^{-1} \mathrm{~cm}^{2} \mathrm{~mol}^{-1}$, in agreement with their $1: 2$ electrolytic character [34]. Analytical results are in agreement with the proposed formulae.

The infrared spectra of the complexes are marked by displacement of the diagnostic bands $v C-N\left(1577-1592 \mathrm{~cm}^{-1}\right)$ and $v C=S$ $\left(633-671 \mathrm{~cm}^{-1}\right)$ compared to the free thioureas (1557$1567 \mathrm{~cm}^{-1}$ and $700-730 \mathrm{~cm}^{-1}$, respectively) [35,36]. Therefore, the observed shift to lower frequency for the mode $v \mathrm{C}=\mathrm{S}$ and concomitant increase in the frequency of $\mathrm{vC}-\mathrm{N}$ absorption is in agreement with thiourea coordination via the sulfur atom $[37,38]$. In addition, characteristic bands due to phenanthroline in the region of $3100 \mathrm{~cm}^{-1}(\mathrm{vCH}), 1350-1500 \mathrm{~cm}^{-1}\left(\mathrm{vCC}_{\text {ring }}\right.$ and $\left.\mathrm{vCN}_{\text {ring }}\right)$ and 
$700-850 \mathrm{~cm}^{-1}(\gamma \mathrm{CH})$ are also present in the spectra of the complexes [29,39].

The electronic absorption spectra of the complexes were recorded in tris- $\mathrm{HCl} / \mathrm{NaCl}$ buffer solution, $\mathrm{pH}$ 7.2. The complexes exhibit intense bands around $220 \mathrm{~nm}$ and $270 \mathrm{~nm}$ based on intraligand $\pi \rightarrow \pi^{*}$ transition [40]. The broad band at $360 \mathrm{~nm}$ can be assigned to a combination of a charge transfer from the ligand to the metal $(S \rightarrow P d)$ and a $d-d$ transition [41].

\subsection{Stability studies}

The stability of complexes $\mathbf{1 - 3}$ in buffer (tris- $\mathrm{HCl} / \mathrm{NaCl}$ ) was checked through ${ }^{1} \mathrm{H}$ NMR experiments. Initially, a spectrum was obtained from a freshly prepared solution of complex. Then, ${ }^{1} \mathrm{H}$ NMR spectra were recorded 1, 2, 4, 8, 12, 24 and 48 h later. In all cases, the observed signals did not differ from that obtained originally. This result certifies the stability of the prepared compounds in buffer solution up to $48 \mathrm{~h}$.

\subsection{Interaction with guanosine}

The platination of DNA is generally associated with the antitumor activity of cisplatin and their analogues, especially at guanine-N7-position [2]. In this work, guanosine was used as a model system to study the reactivity of complexes 1-3. The reaction was accompanied by ${ }^{1} \mathrm{H}$ NMR after $1,2,24$ and $48 \mathrm{~h}$ (Fig. 2).

A downfield shift for the guanosine $\mathrm{H} 8$ signal is expected when the coordination of the nucleotide to metal occurs through guanine-N7 [42]. However, even after 48 h, only a slight upfield shift $(\sim 0.2 \mathrm{ppm})$ could be noted in guanosine signals. These findings indicate that in these conditions the complexes are not able to interact with guanosine through covalent binding. The strong interaction between S-donor nucleophiles and $\mathrm{Pd}(\mathrm{II}) / \mathrm{Pt}(\mathrm{II})$ complexes is predict by the HSAB theory [43]. The literature also presents a great number of studies focused on competition experiments between $\mathrm{Pd}(\mathrm{II}) / \mathrm{Pt}(\mathrm{II})$ complexes and different nucleophiles as sulfur-containing ligands and nucleotides [44]. Petrović et al. have demonstrated in a series of experiments that the most stable complex formed by $\left[\mathrm{Pd}(\operatorname{tpdm})\left(\mathrm{H}_{2} \mathrm{O}\right)\right]^{2+}$ (where tpdm $=$ tripyridinedimethane) is with thiourea, $K=6.7 \times 10^{5} \mathrm{M}^{-1}$, whereas significantly lower values of ca. $10^{3} \mathrm{M}^{-1}$ exist for the other studied nucleophiles, including 5'-GMP (guanosine 5'-monophosphate) [45]. Although the $\mathrm{Pt}(\mathrm{II})$-sulfur interactions were first associated with negative phenomena in the biological environment (i.e. side effects, tumor resistance), they can have benefits in terms of chemoprotective ability and optimal transportation [35]. In order to acquire more information about the type of interaction between the complex and guanosine, a concentration dependence experiment has been carried out using NMR spectroscopy and $\mathrm{pH} / \mathrm{pD}$ measurements [46] (see Supplementary material). On increasing the ratio [guanosine]/[complex], it was detected a gradual upfield shift of $\mathrm{H} 8$ signal of guanosine together with a small variation of the $\mathrm{pH} / \mathrm{pD}$ values (ca. 0.2 ). These findings suggest that the complex may interact with guanosine by stacking interaction.

\subsection{Interaction with supercoiled plasmid}

The ability of 1-3 to interact with DNA was determined by a gel electrophoresis assay using the circular pNFkB-luc plasmid. It is well established that small molecules can bind to a plasmid DNA,
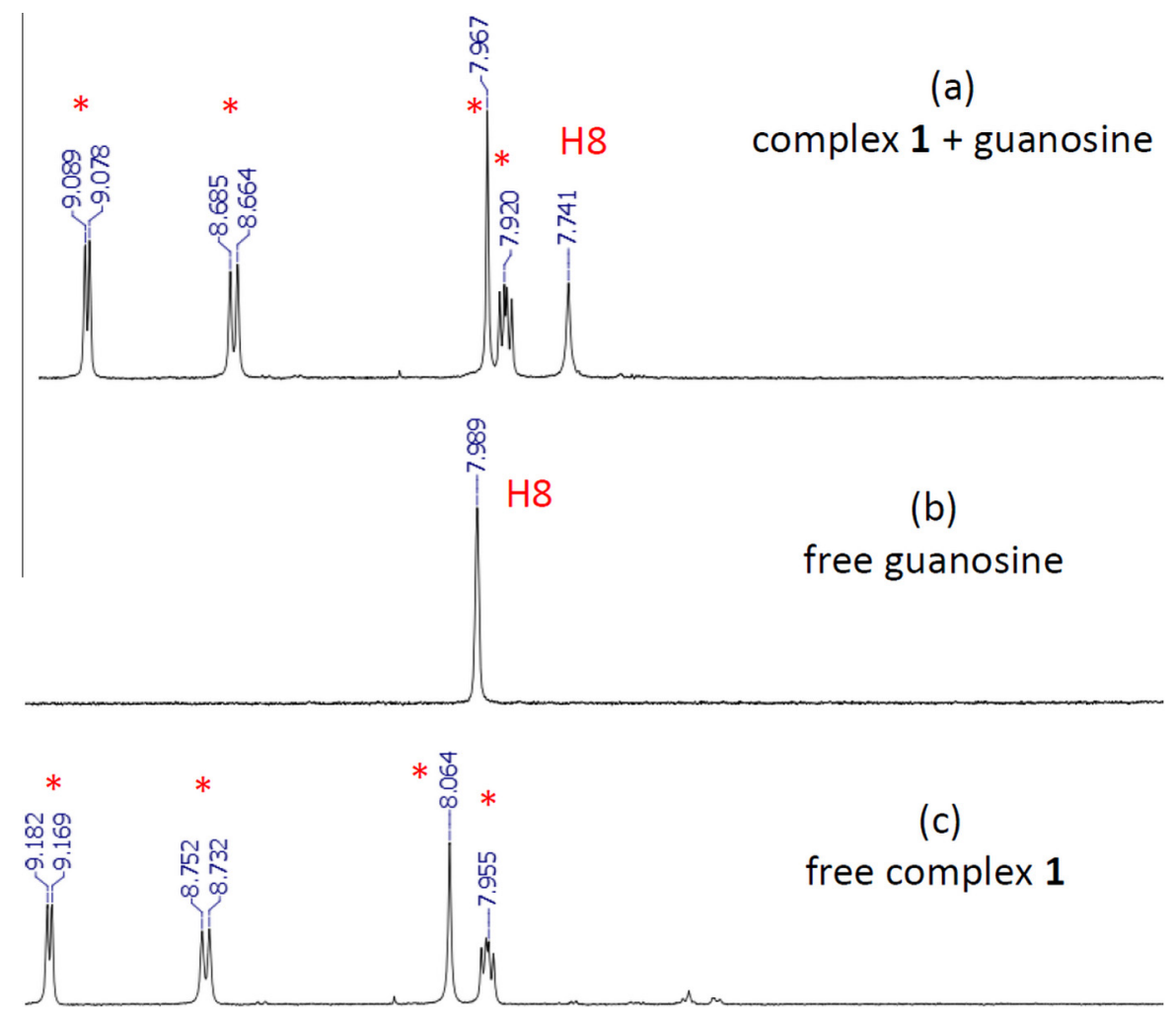

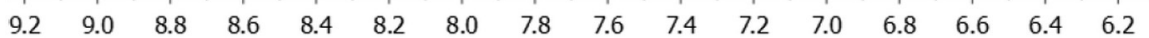

Fig. 2. ${ }^{1} \mathrm{H}$ NMR spectra of guanosine in the presence of complex 1 after $48 \mathrm{~h}$ (a); free guanosine (b) and free complex $\mathbf{1}$ (c). 
changing its length and shape, which results in the unwinding of supercoiled DNA [47]. Therefore, the interaction of a complex with plasmid DNA is confirmed by the reduction in DNA electrophoretic mobility.

Fig. 3 illustrates the electropherogram of pNFkB-luc plasmid DNA incubated with the synthesized compounds at 1,10 or $100 \mu \mathrm{M}$ concentration. Line 1 shows supercoiled plasmid as control in water. The fast migration can be observed for the supercoiled form, whereas the open circular form migrates slowly. For comparison, incubation of DNA with cisplatin (Line 2) was also performed at $10 \mu \mathrm{M}$ under the same conditions. As expected, a relaxation of plasmid structure could be noted. Lines 3-11 present the behavior of pNFkB-luc in the presence of complexes 1-3. Although no changes were observed for all complexes at $1 \mu \mathrm{M}$ (Lines 3, 6 and 9 ), all of them revealed ability to interact with DNA at greater concentrations. Except for complex $\left[\mathrm{Pd}(\right.$ phen $\left.)(\mathrm{mtu})_{2}\right] \mathrm{Cl}_{2}(\mathbf{2})$, they were able to cause DNA unwinding at $10 \mu \mathrm{M}$ and $100 \mu \mathrm{M}$. Under the present experimental conditions, compound $\mathbf{2}$ has only interacted with pNFkB-luc at $100 \mu \mathrm{M}$.

Although the exact mechanism of interaction was not determined in the present experiment, the gel electrophoresis assay has demonstrated the ability of 1-3 to interact with DNA, probably via non-covalent binding. In order to clarify the origin of this interaction, some spectroscopic experiments have been carried out as follows.

\subsection{DNA-binding study with UV spectroscopy}

Titration with UV absorption spectroscopy is commonly employed to study the interaction of metal complexes with DNA. The intercalation mode is characterized by hypochromism and bathochromism due to $\pi \rightarrow \pi^{*}$ stacking interactions between the aromatic complex and the base pairs of DNA [48].

\section{$\begin{array}{lllllllllll}\text { L1 } & \text { L2 } & \text { L3 } & \text { L4 } & \text { L5 } & \text { L6 } & \text { L7 } & \text { L8 } & \text { L9 } & \text { L10 } & \text { L11 }\end{array}$}

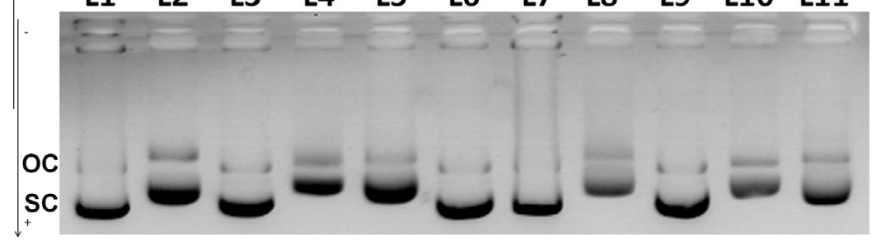

Fig. 3. Plasmid incubation with 1-3 and cisplatin after $24 \mathrm{~h}$. Line 1 : plasmid in water. Line 2: cisplatin $(10 \mu \mathrm{M})$. Line 3: $1(1 \mu \mathrm{M})$. Line 4: $1(10 \mu \mathrm{M})$. Line 5: 1 $(100 \mu \mathrm{M})$. Line 6: $2(1 \mu \mathrm{M})$. Line $7: 2(10 \mu \mathrm{M})$. Line $8: 2(100 \mu \mathrm{M})$. Line $9: 3(1 \mu \mathrm{M})$. Line 10: $3(10 \mu \mathrm{M})$. Line 11: $3(100 \mu \mathrm{M})$. OC represents open circular pDNA and SC indicates supercoiled pDNA.
The typical titration curves for the complexes 1-3 at constant concentration $(40 \mu \mathrm{M})$ in the presence of different amounts of SS-DNA $(0-70 \mu \mathrm{M})$ are illustrated in Fig. 4. The spectral changes observed upon addition of DNA to the complexes clearly show the interaction complex-DNA. The band centred between 268 and $275 \mathrm{~nm}$ in the free complexes exhibits strong hypochromism and small red shift (Table 1), consistent with the DNA intercalative mode [48].

The intrinsic binding constants $\left(K_{\mathrm{b}}\right)$ of the complexes were in the range of $10^{4}-10^{5}$. Although these values are lower than that of the classical intercalator ethidium bromide $(\mathrm{EB})\left(K_{\mathrm{b}}=1.4 \times 10^{6}\right.$ $\mathrm{M}^{-1}$ ), they are comparable to that of others square-planar intercalators $[13,18,49,50]$. As can be seen by the bathochromic shifts, hypochromicities and $K_{\mathrm{b}}$ values of the complexes, there is no significant difference in their binding affinity. This result suggests that the studied ancillary ligands do not affect the intercalating ability of these compounds. Similar observation has been reported $[20]$ for the complexes $\left[\mathrm{Pt}(\mathrm{bpy})(\mathrm{S}-\mathrm{R})_{2}\right]^{2+}(\mathrm{S}-\mathrm{R}=$ thiourea or substituted thiourea), where their binding affinity to DNA was independent of the ancillary ligand.

\subsection{Competitive studies with ethidium bromide}

The ethidium bromide fluorescence displacement experiment has been carried out to clarify the mode of binding between complexes 1-3 and SS-DNA. The intercalation of EB to DNA is accompanied by intense fluorescence emission due to the formation of the EB-DNA complex [51]. When a second molecule intercalates into DNA, there is a reduction of the number of binding sites on the DNA available to EB giving rise to reduction in the fluorescence intensity [48].

The complexes have not shown any significant fluorescence at room temperature in solution or in the presence of SS-DNA. A solution of SS-DNA was pretreated with EB and then titrated with compounds 1-3. The emission spectra obtained in the absence and presence of increasing amounts of $\mathrm{Pd}(\mathrm{II})$ concentrations are given in Fig. 5. When the molar ratio of the complexes to SS-DNA $(r=[$ complex $] /[D N A])$ ranges from 0 to 1.135 , a great decrease of

Table 1

Hypochromism, red shift and binding constant $\left(K_{\mathrm{b}}\right)$ for complexes-DNA interaction.

\begin{tabular}{lllll}
\hline Compound & $\begin{array}{l}\lambda \\
(\mathrm{nm})\end{array}$ & $\begin{array}{l}\text { Hypochromism } \\
(\%)\end{array}$ & $\begin{array}{l}\text { Red shift } \\
(\mathrm{nm})\end{array}$ & $K_{\mathrm{b}}\left(\mathrm{M}^{-1}\right)$ \\
\hline$\left[\mathrm{Pd}(\right.$ phen $\left.)(\mathrm{tu})_{2}\right] \mathrm{Cl}_{2}(\mathbf{1})$ & 268 & 45 & 2 & $(8.6 \pm 0.4) \times 10^{4}$ \\
{$\left[\mathrm{Pd}(\right.$ phen $\left.)(\mathrm{mtu})_{2}\right] \mathrm{Cl}_{2}(\mathbf{2})$} & 271 & 46 & 4 & $(6.7 \pm 0.7) \times 10^{4}$ \\
{$\left[\mathrm{Pd}(\right.$ phen $\left.)(\mathrm{dmtu})_{2}\right] \mathrm{Cl}_{2}(\mathbf{3})$} & 275 & 40 & 3 & $(7.3 \pm 0.9) \times 10^{4}$ \\
\hline
\end{tabular}
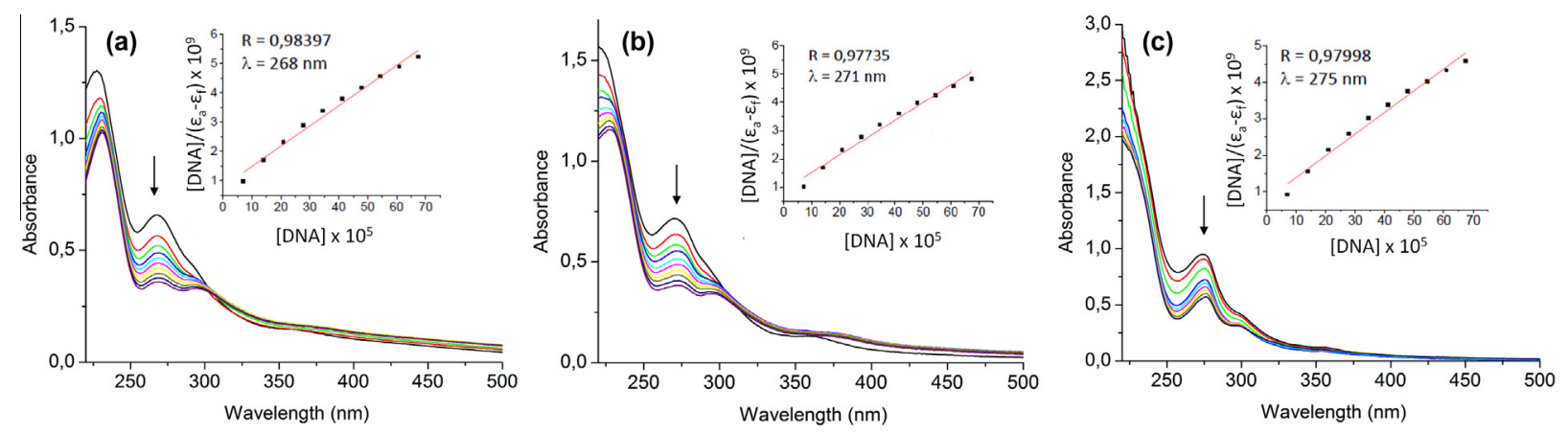

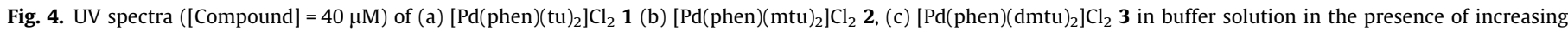
amounts of SS-DNA. The arrows show the changes upon increasing amounts of SS-DNA. Inset: plot of [DNA]/( $\left.\varepsilon_{\mathrm{a}}-\varepsilon_{\mathrm{f}}\right)$ versus [DNA]. 

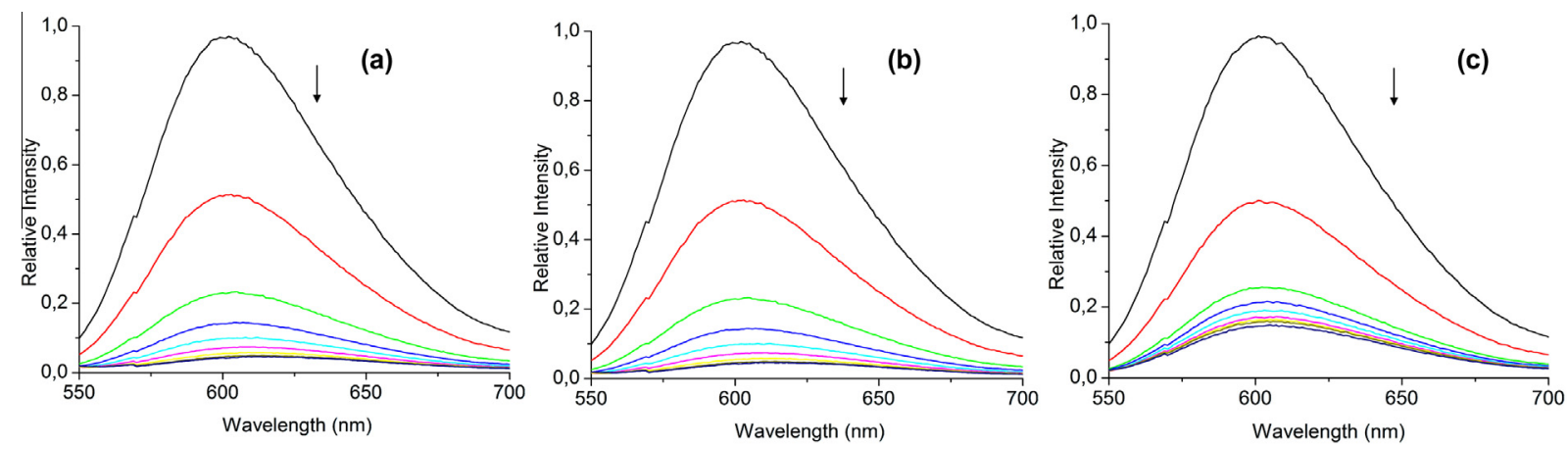

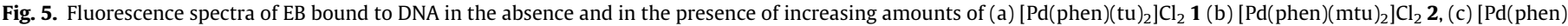
$\left.(\mathrm{dmtu})_{2}\right] \mathrm{Cl}_{2} 3\left([\mathrm{DNA}]=25 \mu \mathrm{M} ;[\mathrm{EB}]=5 \mu \mathrm{M} ;[\right.$ complex $\left.] /[\mathrm{DNA}]=0-2.255 ; \lambda_{\mathrm{ex}}=526 \mathrm{~nm}\right)$.

fluorescence has been observed. However, by adding more complex (ranging from 1.415 to 2.255 ) the fluorescence has decreased gradually, which may be possibly associated with the existence of different binding modes/binding pockets for the intercalators. In the "intense quenching" stage, the EB molecules from the lowaffinity binding sites are initially replaced. During the subsequent "gradual quenching", additional EB is substituted from higheraffinity binding sites. The ability of the complexes 1-3 to quench the fluorescence in a system EB-DNA is in agreement with the titration spectroscopic studies, that indicate their intercalation in DNA.

\subsection{Cytotoxicity in vitro study}

The effect of complexes 1-3 on human oral carcinoma cell line (KB), human breast cancer cell line (MCF7) and cisplatin-resistant human breast cancer cell line (MCF7-R) was assessed by MTT assay [33] and is depicted on Table 2.

All the studied compounds exhibited cytotoxic activity dosedependent. As shown in Table 2, complexes have not demonstrated cytotoxicity on cells at the lowest concentration tested $(1 \mu \mathrm{M})$. Nevertheless, growth inhibition has been observed on KB and MCF7-R cell lines as the concentration increased $(10 \mu \mathrm{M})$. It is important to note that 1-3 were not active against the cisplatinsensitive cell line MCF7, but showed good cell growth inhibition towards the resistant line MCF7-R.

According to the obtained data, complex $\left[\mathrm{Pd}(\right.$ phen $\left.)(\mathrm{tu})_{2}\right] \mathrm{Cl}_{2}(\mathbf{1})$ revealed to be the less cytotoxic of the series inhibiting the cell growth about ten and two times less than $\left[\mathrm{Pd}(\right.$ phen $\left.)(\mathrm{mtu})_{2}\right] \mathrm{Cl}_{2}$ (2) and $\left[\mathrm{Pd}(\mathrm{phen})(\mathrm{dmtu})_{2}\right] \mathrm{Cl}_{2}(\mathbf{3})$ on KB and MCF7-R, respectively. Since the three complexes display the same intercalating ligand (phen) and similar DNA-intercalation ability, as discussed above, we speculate that the difference on their cytotoxicity might be attributed to the ancillary ligand. Differences on thioureas structure could directly affect biological properties of the complexes. There are many reports indicating that increases on lipophilicity generally results on greater cellular uptake and cytotoxicity $[52,53]$. In addition, the substituents on thiourea moiety can modify the acidity of the thioureido - $\mathrm{NH}$ protons and their ability to

Table 2

The \% growth inhibition of complexes 1-3 at $1 \mu \mathrm{M}$ and $10 \mu \mathrm{M}$ concentration on $\mathrm{KB}$, MCF7 and MCF7-R cell lines.

\begin{tabular}{|c|c|c|c|c|c|c|}
\hline \multirow[t]{2}{*}{ Compound } & \multicolumn{2}{|l|}{ KB } & \multicolumn{2}{|l|}{ MCF7 } & \multicolumn{2}{|c|}{ MCF7-R } \\
\hline & $10 \mu \mathrm{M}$ & $1 \mu \mathrm{M}$ & $10 \mu \mathrm{M}$ & $1 \mu \mathrm{M}$ & $10 \mu \mathrm{M}$ & $1 \mu \mathrm{M}$ \\
\hline$\left[\mathrm{Pd}(\right.$ phen $\left.)(\mathrm{tu})_{2}\right] \mathrm{Cl}_{2}(\mathbf{1})$ & $2 \pm 5$ & $0 \pm 17$ & $0 \pm 10$ & $0 \pm 8$ & $30 \pm 2$ & $0 \pm 3$ \\
\hline$\left[\mathrm{Pd}(\right.$ phen $\left.)(\mathrm{mtu})_{2}\right] \mathrm{Cl}_{2}(\mathbf{2})$ & $26 \pm 2$ & $0 \pm 6$ & $0 \pm 15$ & $0 \pm 3$ & $64 \pm 1$ & $0 \pm 2$ \\
\hline$\left[\mathrm{Pd}(\right.$ phen $\left.)(\mathrm{dmtu})_{2}\right] \mathrm{Cl}_{2}(\mathbf{3})$ & $23 \pm 7$ & $0 \pm 2$ & $0 \pm 6$ & $0 \pm 7$ & $59 \pm 1$ & $0 \pm 4$ \\
\hline
\end{tabular}

form hydrogen bonding [54], which could influence the antitumor activity of the complexes. As shown in Fig. 2, compounds 1-3 may probably interact to guanosine through hydrogen bonding. Nevertheless, it is important to emphasize that such structure-activity relationship proposed in this study is very preliminary since it was based on only three $\mathrm{Pd}(\mathrm{II})$ compounds.

\subsection{Topoisomerase inhibition}

Topoisomerases are essential enzymes involved in DNA replication, transcription, chromosome condensation and chromosome segregation [55]. It has been demonstrated that topoisomerase II inhibition is involved in the mechanism of action of many intercalators as doxorubicin and mitoxantrone [56]. The cytotoxic effects of these agents may be mediated by the formation of an intermediate covalent DNA-topoisomerase II complex, which results in cell death via apoptosis [8].

A considerable interest has recently been focused on metal compounds containing 1,10-phenanthroline ligands, particularly in their ability to act as effective topoisomerase II inhibitors [5761]. The ability of compounds $\mathbf{1 - 3}$ to intercalate has also prompted us to consider topoisomerase II as another possible target of such complexes. The effect of the complexes in DNA relaxation catalyzed by human topoisomerase II is shown in Fig. 6. Lines 1 and 2 represent the DNA plasmid control in water in the absence and presence of topo II, respectively.

The results in the presence of compounds 1-3 (Lines 3-11) demonstrated that $\left[\mathrm{Pd}(\right.$ phen $\left.)(\mathrm{mtu})_{2}\right] \mathrm{Cl}_{2}(\mathbf{2})$ and $\left[\mathrm{Pd}(\right.$ phen $\left.)(\mathrm{dmtu})_{2}\right]$ $\mathrm{Cl}_{2}$ (3) can inhibit topo II activity in a dose-dependent manner, being the complex 3 the most potent inhibitor since it produces inhibition at small concentration $(1 \mu \mathrm{M})$. This finding may indicate that the studied complexes, as DNA intercalators, could bind to the DNA-topo complex acting as a topo II poison [23]. However, [Pd (phen) $\left.(\mathrm{tu})_{2}\right] \mathrm{Cl}_{2}$ (1) could not avoid the decatenation of DNA

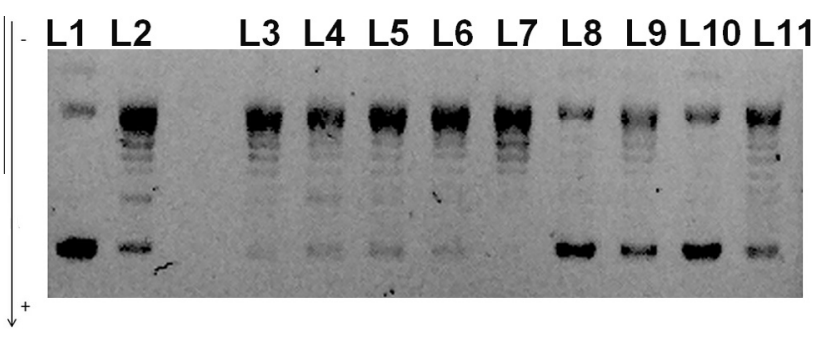

Fig. 6. Effects of different concentrations of complexes 1-3 on the activity of DNA topoisomerase II. Line 1: plasmid in water. Line 2: plasmid and topo II in water. Line 3: $1(1 \mu \mathrm{M})$. Line 4: $1(10 \mu \mathrm{M})$. Line 5: $1(100 \mu \mathrm{M})$. Line $6: 2(1 \mu \mathrm{M})$. Line $7: 2$ $(10 \mu \mathrm{M})$. Line 8: $2(100 \mu \mathrm{M})$. Line 9: $3(1 \mu \mathrm{M})$. Line 10: $3(10 \mu \mathrm{M})$. Line 11: 3 $(100 \mu \mathrm{M})$. 
performed by the enzyme in a concentration range between 1 and $100 \mu \mathrm{M}$. Although a mechanism of action cannot be exactly proposed, it can be seen for the experiments that slight changes in the structure can deeply affect their interaction toward topo II enzyme.

\section{Conclusions}

We have shown that for the series of compounds $[\operatorname{Pd}($ phen) $\left.\left(\mathrm{tu}^{*}\right)_{2}\right]^{2+}$ the DNA binding constants $\left(K_{\mathrm{b}}\right)$ were $4.8 \times 10^{4} \mathrm{M}^{-1}$ $7.0 \times 10^{4} \mathrm{M}^{-1}$, which is typical of metallointercalators. In addition, all the complexes were able to displace EB from the DNA-EB complex, which is also indicative of their intercalative mode of binding. Also, their reaction with guanosine has not occurred, excluding the possibility of covalent interaction with DNA. Concerning to cytotoxicity, although the complexes were inactive towards the sensitive MCF7 cells at $10 \mu \mathrm{M}$, they showed good cytotoxic activity towards the resistant MCF7-R. This finding suggest that the cytotoxicity mechanisms of the $\mathrm{Pd}(\mathrm{II})$ compounds differ from that observed for cisplatin. Complexes $\mathbf{2}$ and $\mathbf{3}$ were more active than 1 in both KB and MCF7-R cells. From DNA binding experiments, it can be suggested that for these compounds the ancillary ligand does not affect the intercalating ability, indicating that DNA binding affinity is not a key determinant of the observed difference in their cytotoxicity. Nevertheless, differences on thiourea structure could directly affect cytotoxic effects of the complexes. It is also important to note that compounds $\mathbf{2}$ and $\mathbf{3}$ were able to inhibit topo II, which could be related to the observed results. On the other hand, additional pharmacological targets can not be excluded and more studies are necessary to elucidate their mechanism of action.

\section{Acknowledgments}

We thank the São Paulo State University (UNESP), Institute of Chemistry of Araraquara. This work was sponsored by FAPESP 2014/11340-0, CNPq and CAPES.

\section{Appendix A. Supplementary material}

Supplementary data associated with this article can be found, in the online version, at http://dx.doi.org/10.1016/j.ica.2016.02.053.

\section{References}

[1] B. Rosemberg, Nature 222 (1969) 385.

[2] L. Kelland, Nat. Rev. Cancer 7 (2007) 573.

[3] A.M. Pizarro, P.J. Sadler, Biochimie 91 (2009) 1198.

[4] L. Strekowski, B. Wilson, Mut. Res. 623 (2007) 3.

[5] L.S. Lerman, J. Mol. Biol. 3 (1961) 18.

[6] N.J. Wheate, C.R. Brodie, J.G. Collins, S. Kemp, J.R. Aldrich-Wright, Mini-Rev. Med. Chem. 7 (2007) 627.

[7] B.M. Zeglis, V.C. Pierre, J.K. Barton, Chem. Commun. 44 (2007) 4565

[8] K.R. Hande, Update Cancer Ther. 3 (2008) 13.

[9] M.J. Hannon, Pure Appl. Chem. 79 (2007) 2243.

[10] J.K. Barton, E.D. Olmon, Coord. Chem. Rev. 255 (2011) 619.

[11] M.J. Hannon, Chem. Soc. Rev. 36 (2007) 280.

[12] H.-K. Liu, P.J. Sadler, Acc. Chem. Res. 44 (2011) 349.

[13] C.R. Brodie, J.G. Collins, J.R. Aldrich-Wright, Dalton Trans. (2004) 1145-1152.

[14] E.-J. Gao, L. Wang, M.-C. Zhu, L. Liu, W.-Z. Zhang, E. J. Med. Chem. 45 (2010) 311.

[15] H. Mansouri-Torshizi, M. Saeidifar, A. Divsalar, A.A. Saboury, S. Shahraki, Spectrochim. Acta 77 (2010) 312-318.

[16] M. Cusumano, M.L. Di Pietro, A. Giannetto, Chem. Commun. 22 (1996) 2527.
[17] M. Cusumano, M.L. Di Pietro, A. Giannetto, F. Nicolò, E. Rotondo, Inorg. Chem. 37 (1998) 563.

[18] S. Kemp, N.J. Wheate, D.P. Buck, M. Nikac, J.G. Collins, J.R. Aldrich-Wright, J Inorg. Biochem. 101 (2007) 1049.

[19] M.C. Ackley, C.G. Barry, A.M. Mounce, M.C. Farmer, B.E. Springer, C.S. Day, M.W. Wright, S.J. Berners-Price, S.M. Hess, U. Bierbach, J. Biol. Inorg. Chem. 9 (2004) 453.

[20] M. Cusumano, M.L. Di Pietro, A. Gianetto, P.A. Vainiglia, J. Inorg. Biochem. 99 (2005) 560.

[21] A. Rotondo, S. Barresi, M. Cusumano, E. Rotondo, Polyhedron 45 (2012) 23.

[22] A. Rotondo, S. Barresi, M. Cusumano, E. Rotondo, P. Donato, L. Mondello, Inorg. Chim. Acta 410 (2014) 1.

[23] G. Marverti, M. Cusumano, A. Ligabue, M.L. Di Pietro, P.A. Vainiglia, A. Ferrari, M. Bergomi, M.S. Moruzzi, C. Frassineti, J. Inorg. Biochem. 102 (2008) 699.

[24] F.V. Rocha, C.V. Barra, A.E. Mauro, I.Z. Carlos, L. Nauton, M. El Ghozzi, A. Gautier, L. Morel, A.V.G. Netto, Eur. J. Inorg. Chem. 25 (2013) 4499.

[25] C.V. Barra, F.V. Rocha, A. Gautier, L. Morel, M.B. Quilles, I.Z. Carlos, O. TreuFilho, R.C.G. Frem, A.E. Mauro, A.V.G. Netto, Polyhedron 65 (2013) 214.

[26] J.G. Ferreira, A. Stevanato, A.M. Santana, A.E. Mauro, A.V.G. Netto, R.C.G. Frem, F.R. Pavan, C.Q.F. Leite, R.H.A. Santos, Inorg. Chem. Commun. 23 (2012) 63.

[27] A.C. Moro, A.E. Mauro, A.V.G. Netto, S.R. Ananias, M.B. Quilles, I.Z. Carlos, F.R. Pavan, C.Q.F. Leite, M. Horner, Eur. J. Med. Chem. 44 (2009) 4611.

[28] R.F. Heck, Palladium reagents in organic synthesis: best synthetic methods, Academic Press, London, 1985.

[29] D.J. Awad, F. Conrad, A. Koch, U. Schilde, O. Poppl, A. Strauch, Inorg. Chim. Acta 363 (2010) 1488-1494.

[30] J. Marmur, J. Mol. Biol. 3 (1961) 208.

[31] M.E. Reichmann, C.A. Rice, C.A. Thomas, P. Doty, J. Am. Chem. Soc. 76 (1954) 3047.

[32] Mudasir, N. Yoshioka, H. Inoue, J. Inorg. Biochem. 77 (1999) 239-247.

[33] T. Mossman, J. Immunol. Meth. 65 (1983) 55.

[34] W.J. Geary, Coord. Chem. Rev. 7 (1971) 81.

[35] L. Fuks, N. Sadlej-Sosnowska, K. Samochocka, W. Starost, J. Mol. Struct. 740 (2005) 229.

[36] Y. Mido, I. Kitagawa, M. Hashimoto, H. Matsuura, Spectrochim. Acta A 55 (1999) 2623.

[37] S. Ahmad, A.A. Isab, S. Ahmad, J. Coord. Chem. 56 (2003) 1587.

[38] A. Yamaguchi, R.B. Penland, S. Mizushima, J.T. Lane, C. Curran, J.V. Quagliano, J. Am. Chem. Soc. 80 (1958) 527-529.

[39] M.M. Campos-Vallette, R.E. Clavijo, F. Mendizabal, W. Zamudio, R. Baraona, G. Diaz, Vib. Spectrosc. 12 (1996) 37.

[40] P.U. Maheswari, M. Palaniandavar, J. Inorg. Biochem. 98 (2004) 219.

[41] A.K. Mishra, N.K. Kaushik, Eur. J. Med. Chem. 42 (2007) 1239.

[42] A. Chevry, M.-L. Teyssot, A. Maisonial, P. Lemoine, B. Viossat, M. Traïkia, D.J Aitken, G. Alves, L. Morel, L. Nauton, A. Gautier, Eur. J. Inorg. Chem. (2010) 3513-3519.

[43] R.G. Pearson, J. Chem. Educ. 45 (1968) 581.

[44] J. Reedijk, Chem. Rev. 99 (1999) 2499.

[45] B. Petrović, Ž.D. Bugarčić, A. Dees, I. Ivanović-Burmazović, F.W. Heinemann, R. Puchta, S.N. Steinmann, C. Corminboeuf, R. van Eldik, Inorg. Chem. 51 (2012) 1516.

[46] C.S. Ferreira, A.M.C. Pimenta, C. Demicheli, F. Frézard, Biometals 19 (2006) 573.

[47] M.V. Keck, S.J. Lippard, J. Am. Chem. Soc. 114 (1992) 3386.

[48] M. Sirajuddin, S. Ali, A. Badshah, J. Photochem. Photobiol. B 124 (2013) 1.

[49] M. Cusumano, M.L. Di Pietro, A. Giannetto, Inorg. Chem. 38 (1999) 1754.

[50] T. Afrati, A.A. Pantazaki, C. Dendrinou-Samara, C. Raptopoulou, A. Terzis, D.P. Kessissoglou, Dalton Trans. 39 (2010) 765.

[51] J. Olmsted III, D.R. Kearns, Biochemistry 16 (1977) 3647.

[52] E. Gao, M. Zhu, L. Liu, Y. Huang, L. Wang, C. Shi, W. Zhang, Y. Sun, Inorg. Chem. 49 (2010) 3261.

[53] H. Silva, C.V. Barra, C.F. da Costa, M.V. de Almeida, E.T. César, J.N. Silveira, A Garnier-Suillerot, F.C.S. de Paula, E.C. Pereira-Maia, A.P.S. Fontes, J. Inorg. Biochem. 102 (2008) 767.

[54] L. Nie, Z. Li, J. Han, X. Zhang, R. Yang, W.X. Liu, F.Y. Wu, J.W. Xie, Y.F. Zhao, Y.B Jiang, J. Org. Chem. 69 (2004) 6449.

[55] Y. Pommier, ACS Chem. Biol. 8 (2013) 82.

[56] Y. Pommier, E. Leo, H. Zhang, C. Marchand, Chem. Biol. 17 (2010) 421.

[57] J.-F. Kou, C. Qian, J.-Q. Wang, X. Chen, L.-L. Wang, H. Chao, L.-N. Ji, J. Biol. Inorg. Chem. 17 (2012) 81

[58] X. Chen, F. Gao, W.-Y. Yang, Z.-X. Zhou, J.-Q. Lin, L.-N. Ji, Chem. Biodivers. 10 (2013) 367.

[59] X. Chen, F. Gao, Z.-X. Zhou, W.-Y. Yang, L.-T. Guo, L.-N. Ji, J. Inorg. Biochem. 104 (2010) 576.

[60] K.-J. Du, J.-Q. Wang, J.-F. Kou, G.-Y. Li, L.-L. Wang, H. Chao, L.-N. Ji, Eur. J. Med. Chem. 46 (2011) 1056.

[61] F. Gao, C. Hui, F. Zhou, X. Chen, Y.-F. Wei, L.-N. Ji, J. Inorg. Biochem. 102 (2008) 1050. 